Bull. Chem. Soc. Ethiop. 2019, 33(1), 127-134.

ISSN 1011-3924

(c) 2019 Chemical Society of Ethiopia and The Authors

Printed in Ethiopia

DOI: https://dx.doi.org/10.4314/bcse.v33i1.12

\title{
THE APPLICATION OF DISPERSE DYES DERIVED FROM 4-BROMOANILINE AND 3-CHLOROANILINE ON TO POLYESTER FABRIC
}

\author{
J.O. Otutu ${ }^{1}$, E.K. Ossai ${ }^{1}$, S.U. Ameuru ${ }^{2}$, P.O. Itoya ${ }^{1}$ and W.E. Morka ${ }^{1}$ \\ ${ }^{1}$ Department of Chemistry, Faculty of Science Delta State University, P.M.B. 1 Abraka, Nigeria \\ ${ }^{2}$ Department of Polymer and Textile Engineeering, Ahmadu Bello University, Zaria, Nigeria
}

(Received March 22, 2018; Revised December 13, 2018; Accepted December 20, 2018)

\begin{abstract}
A series of new disazo disperse dye compounds based on 4-amino-2-chlorophenylazo-4bromobenzene intermediate were prepared by linking various arylamines and phenolic derivatives to this intermediate through diazo coupling reactions. The structures of the azo compounds were confirmed by FT-IR, ${ }^{1} \mathrm{H}$ NMR, ${ }^{13} \mathrm{C}$ NMR and UV-visible spectral data. The results of the UV-vis absorption spectra of some of the dyes showed near-infrared absorptions around 573-800 $\mathrm{nm}$. The results of the colour fastness to washing and sublimation gave an excellent value of grade 5. The light fastness values were found to be technically acceptable with the grey-scale grade of 5 to 6-7. Also, the rubbing fastness was observed to be grade $3 / 4$ to 4 .
\end{abstract}

KEY WORDS: Disazo dyes, Spectral absorption, Polyester, Fastness, Near-infrared absorption

\section{INTRODUCTION}

Organic compounds that absorb light in the near-infrared region of the electromagnetic spectrum represent a group of emerging compounds which show great potential for use in many areas of human endeavour [1-3]. Some of these include security-printing such as bank notes, credit cards, passports, invisible inks, and identity cards. Compounds of this type are all considered to contain a conjugated $\pi$-electron system. And for a chromophore to absorb at wavelengths in the near-infrared, the $\pi$-electrons must be delocalised especially along the conjugated chain [4-7]. Near-infrared absorbing organic molecules are compounds that interact with near infrared light and can also emit such near infrared light when under external stimulation like photoexcitation, chemical reactions and electric field [8-10].

Various classes of organic molecules that can be classified as near-infrared absorbers are metal dithiolene complexes, phthalocyanines, naphthacyanines and polymethines. Most of these compounds exhibit extreme stability to high temperatures, chemical stability, photostability and resistant to weather effect. Thus, some of them have been reported to be suitable for applications in the automobile and architectural sectors [4, 8, 11-13].

Recently, the synthesis, characterisation and application of a series of some near-infrared absorbers based on 4-bromoaniline and 3-aminophenol were discussed [13]. The findings obtained from the study, encouraged the authors' to undertake the present work as a continuation of an on-going research program, aiming to synthesize, characterize and apply another series of azo compounds based on 4-bromoaniline and 3-chloroaniline on to synthetic textile substrate. Organic compounds of this type can be used as chromophoric systems for many kinds of applications such as in the dyeing of polyesters, polyamides and acrylics. In addition, they could be used as organic photoconductors, in liquid crystal displays, photosensitizers and other non-textile applications $[11,14,15]$.

*Corresponding author. E-mail: johnsonotutu@gmail.com

This work is licensed under the Creative Commons Attribution 4.0 International License 


\section{EXPERIMENTAL}

\section{Materials and instruments}

4-Bromoaniline and 3-chloroaniline were purchased from Merck (Germany). All other chemicals and solvents were of analytical reagent grades and were used without further purification. A plain woven polyester fabric was used (density 136 x 88, weight 68-70 $\mathrm{gm}^{-2}$ ). The melting points of the dyestuffs were determined on a melting point instrument (Thermo Fisher Scientific, USA) and were reported uncorrected in ${ }^{\circ} \mathrm{C}$. Fourier transform-infrared (FT-IR) spectra were recorded on a Shimadzu IR-8400S spectrometer. Ultraviolet-visible (UV-Vis) absorption spectra were recorded using a Shimadzu UV-2400 double-beam PC spectrophotometer. The ${ }^{1} \mathrm{H}$ NMR spectra and ${ }^{13} \mathrm{C}$ NMR spectra were recorded using a Varian mercury 200BB series spectrometer, respectively, in dimethylsulphoxide (DMSO) $-\mathrm{d}_{6}$, using tetramethylsilane (TMS) as the internal standard.

\section{Synthesis of compound 3}

Compound 1 (10.0 g, $85 \mathrm{mmol})$ was mixed with water $(50 \mathrm{~mL})$ and concentrated sulfuric acid (8 $\mathrm{mL}$ ) and cooled to $0-5{ }^{\circ} \mathrm{C}$. A cold aqueous solution of sodium nitrite $(4.0 \mathrm{~g}, 58 \mathrm{mmol})$ in water was then added slowly over a period of $20-30 \mathrm{~min}$, while maintaining the temperature at $0-5{ }^{\circ} \mathrm{C}$ with vigorous stirring. The reaction mixture was further stirred for $70 \mathrm{~min}$, and excess nitrous acid produced was destroyed by the addition of urea $(0.2 \mathrm{~g})$. The clear diazonium salt solution was then added dropwise with stirring to a well-cooled $\left(0-5{ }^{\circ} \mathrm{C}\right)$ and stirred solution of 3chloroaniline $(6 \mathrm{~mL})$ in glacial acetic acid $(7 \mathrm{~mL})$. Stirring was continued for $2 \mathrm{~h}$ at room temperature and the precipitated product obtained was filtered, washed with water several times, dried and purified by column chromatography (using 100-200 mesh silica gel, ca $100 \mathrm{~g}$ ) and a gradient eluent system with chloroform-methanol $(95: 5, \mathrm{v} / \mathrm{v})$ to afford compound $\mathbf{3}$ with a yield of $85 \%$.

\section{Synthesis of compounds $\mathbf{5 a}$ to $\mathbf{5 f}$}

A well-stirred mixture of compound 3 ( $2 \mathrm{~g}, 0.006 \mathrm{~mol})$, concentrated sulfuric acid ( $5 \mathrm{~mL})$, and water $(30 \mathrm{~mL})$ was thoroughly stirred and cooled in an ice-bath for $3 \mathrm{~min}$. Sodium nitrite $(2.3 \mathrm{~g}$, $0.058 \mathrm{~mol})$ solution in water $(10 \mathrm{~mL})$ was cooled to $0-5{ }^{\circ} \mathrm{C}$ and then added dropwise to the mixture with vigorous stirring for about $20 \mathrm{~min}$. The cold diazonium salt solution obtained was then added dropwise to a well-stirred solution of 4-aminophenol $(1.05 \mathrm{~g}, 0.10 \mathrm{~mol})$ in sodium hydroxide $(1.0 \mathrm{~g})$ dissolved in water $(20 \mathrm{~mol})$ with vigorous stirring. The reaction mixture was further stirred for $2 \mathrm{~h}$ at room temperature and the precipitated product obtained was filtered, washed with water thrice, dried, and recrystallised from ethanol to give compound 5a. Other compounds such as 1,3-dyhydroxybenzene, 1-naphthylamine, 6-aminouracid, 3-aminophenol and 4-hydroxybenzoic acid were used in a coupling reaction with the diazonium salt solution of compound $\mathbf{3}$ to afford compounds $\mathbf{5 b}, \mathbf{5 c}, \mathbf{5 d}, \mathbf{5 e}$ and $\mathbf{5 f}$, respectively.

Dye 5a. Yield 43\%; mp $170{ }^{\circ} \mathrm{C} ;{ }^{1} \mathrm{H}$ NMR (200 MHz, DMSO-d $)$, $\delta$, ppm $2.72\left(\mathrm{~S}, 2 \mathrm{H}, \mathrm{NH}_{2}\right), 4.31$ $\left(\mathrm{s},{ }^{1} \mathrm{H}, \mathrm{OH}\right), 6.64(\mathrm{~m}, 2 \mathrm{H}, \mathrm{ArH}), 6.92\left(\mathrm{~m},{ }^{1} \mathrm{H}, \mathrm{ArH}\right), 7.23-7.70(\mathrm{~m}, 3 \mathrm{H}, \mathrm{ArH}), 7.85-8.20(\mathrm{~m}, 2 \mathrm{H}$, ArH), 8.51-8.75 (m, 2H, ArH), ${ }^{13} \mathrm{C}$ NMR (50 MHz, DMSO-d ${ }_{6}$ ) $\delta \mathrm{c}, \mathrm{ppm} 140.2,145.4,144.7$, 132.5 (all C), 132.5, 122.0, 121.9, 117.5 (all C), 41.3, 40.6, 40.4, 39.8, 39.2, 38.6, 38.4 (all CH), IR $\left(\mathrm{v} \mathrm{cm}^{-1}\right), 35.20-3400\left(\mathrm{ArO}-\mathrm{H}_{\text {str }}\right.$ and $\left.\mathrm{NH}_{\mathrm{str}}\right), 3163-3069\left(\mathrm{ArC}-\mathrm{H}_{\mathrm{str}}\right), 1696-1579\left(\mathrm{ArC}=\mathrm{C}_{\text {str }}\right)$, $\left.1487\left(\mathrm{~N}=\mathrm{N}^{-}\right), 1031\left(\mathrm{C}-\mathrm{O}_{\text {str }}\right), 848\left(\mathrm{C}-\mathrm{H}_{\text {bend }}\right), 788\left(\mathrm{C}-\mathrm{Cl}_{\text {str }}\right), 6579 \mathrm{C}-\mathrm{Br}_{\text {str }}\right)$.

Dye 5b. Yield 65\%, mp $150{ }^{\circ} \mathrm{C} ;{ }^{1} \mathrm{H}$ NMR (200 MHz, DMSO-d $\left.\mathrm{d}_{6}\right), 5$, ppm: $4.22\left(5,{ }^{1} \mathrm{H}, \mathrm{OH}_{\text {str }}\right.$ ), $6.62 \mathrm{~d}, 1 \mathrm{H}, \mathrm{J}=7 \mathrm{H} 2, \operatorname{ArH}), 7.24-7.45(\mathrm{~m}, 2 \mathrm{H}, \operatorname{ArH}), 7.73\left(\mathrm{~m},{ }^{1} \mathrm{H}, \operatorname{ArH}\right), 7.80-8.20(\mathrm{~m}, 4 \mathrm{H}$, 
ArH), 8.42 (m, 2H, ArH), ${ }^{13} \mathrm{C}$ NMR (50 MHz, DMSO-d $\left.\mathrm{d}_{6}\right), \delta_{\mathrm{C}}, \mathrm{ppm}: 147.2,135.9,133.4,131.6$, 128.4, (all C), 123.5, 116.7, 67.5, 41.5, 41.1, 40.8, 40.2, 40.6, 39.5 (all CH); IR ( $v^{-1} \mathrm{~cm}^{-1}$ : 3471$3441\left(\mathrm{Ar} \mathrm{O}-\mathrm{H}_{\text {str }}\right), 3058-2931\left(\mathrm{Ar} \mathrm{C}-\mathrm{H}_{\text {str }}\right), 1614-1583\left(\mathrm{Ar} \mathrm{C}=\mathrm{C}_{\mathrm{str}}\right), 1479\left(-\mathrm{N}=\mathrm{N}^{-}\right), 1064\left(\mathrm{C}-\mathrm{O}_{\text {str }}\right)$, $855\left(\mathrm{C}-\mathrm{H}_{\text {bend }}\right), 759\left(\mathrm{C}-\mathrm{Cl}_{\text {str }}\right), 677\left(\mathrm{C}-\mathrm{Br}_{\mathrm{str}}\right)$.

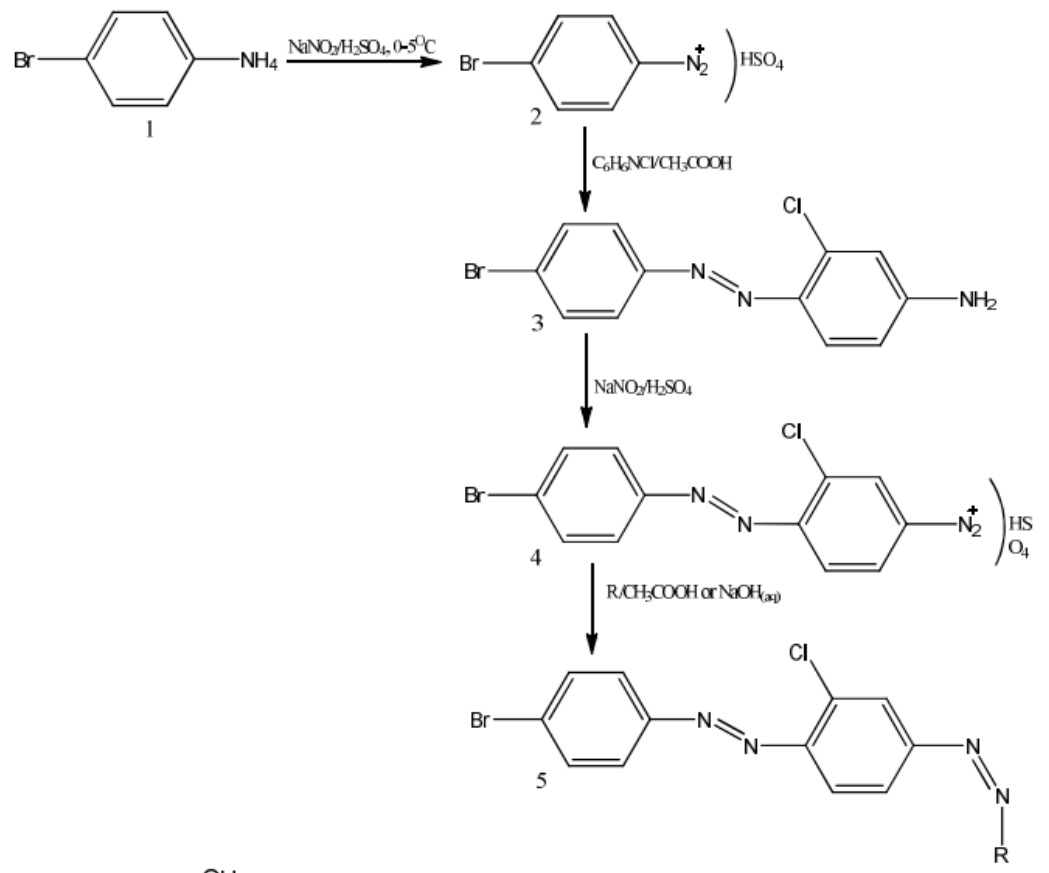

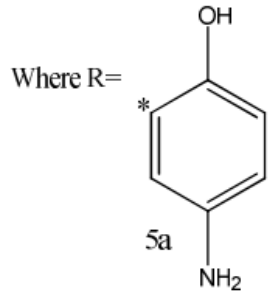<smiles>Nc1cc(O)[nH]c(=O)n1</smiles>

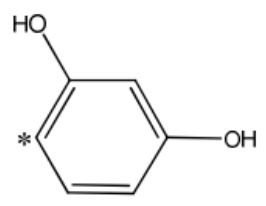

$5 b$

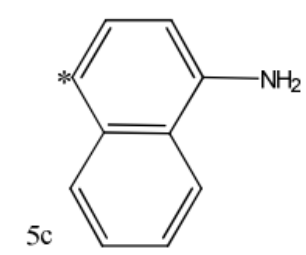

Scheme 1. Synthetic route to compound $\mathbf{3}$ and dyes $\mathbf{5 a}$ to $\mathbf{5 f}$.

Bull. Chem. Soc. Ethiop. 2019, 33(1) 
Dye 5c. Yield 52\%, mp $240{ }^{\circ} \mathrm{C} ;{ }^{1} \mathrm{H}$ NMR (200 MHz, DMSO-d $\left.{ }_{6}\right), \delta_{\mathrm{H}}, \mathrm{ppm}: 2.51(\mathrm{~s}, 2 \mathrm{H}, \mathrm{ArH})$, 6.50-7.53 (m, 6H, naphthyl-H), 7.80-8.22 (m, 3H, ArH), 8.45-8.62 (m, 4H, ArH); ${ }^{3} \mathrm{C}$ NMR (50 MHz, DMSO-d ${ }_{6}$ ), $\delta \mathrm{c}$, ppm: 143.7, 141.4, 133.5, 131.7, 131.4, 125.0 (all C), 123.7, 122.2, 118.6, 116.7, 41.8, 41.5, 40.1, 39.7, 39.5, 39.2, 38.6, 38.4 (all CH); IR $\left(v \mathrm{~cm}^{-1}\right)$ : 3423-3288 $\left(\mathrm{Ar}-\mathrm{NH}_{2}\right)$, 3186-3093 (Ar C-H str $\left._{1}\right), 1678-1589\left(\mathrm{Ar} \mathrm{C}=\mathrm{C}_{\text {str }}\right), 1479(-\mathrm{N}=\mathrm{N}-), 1086\left(\mathrm{C}-\mathrm{O}_{\text {str }}\right), 885,833\left(\mathrm{C}-\mathrm{H}_{\text {bend }}\right)$, $786\left(\mathrm{C}-\mathrm{Cl}_{\text {str }}\right), 677\left(\mathrm{C}-\mathrm{Br}_{\text {str }}\right)$.

Dye 5d. Yield 68\%; mp $180{ }^{\circ} \mathrm{C} ;{ }^{1} \mathrm{H}$ NMR (200 MHz, DMSO- $\left.\mathrm{d}_{6}\right), \delta_{\mathrm{H}}, \mathrm{ppm}: 2.41\left(3,2 \mathrm{H}, \mathrm{NH}_{2}\right)$, $3.84\left(\mathrm{~s},{ }^{1} \mathrm{H}, \mathrm{Ar} \mathrm{O}-\mathrm{H}_{\mathrm{str}}\right) ; 6.72-7.24(\mathrm{~d}, 2 \mathrm{H}, \mathrm{J}=8 \mathrm{~Hz} \mathrm{ArH}) .7 .44-7.67(\mathrm{~m}, 2 \mathrm{H}, \mathrm{ArH}), 7.82-8.24(\mathrm{~m}$, $3 \mathrm{H}, \mathrm{ArH}) 13.01\left(\mathrm{~s},{ }^{1} \mathrm{H} \mathrm{NH}\right) ;{ }^{13} \mathrm{C}$ NMR $\left(50 \mathrm{MHz}, \mathrm{DMSO}-\mathrm{d}_{6}\right) \delta \mathrm{c}, \mathrm{ppm}: 167.8,167.7,($ all $\mathrm{C}=\mathrm{O})$ 145.8, 143.4, 135.2, 132.3, 127.8, 125.5, 118.6 (all C), 76.5, 41.2, 40.8, 40.6, 40.1, 39.6, 38.6, $38.3($ all CH$)$; IR $\left(v^{-1} \mathrm{~cm}^{-1}\right)$; 3471-3416 $\left(\mathrm{O}-\mathrm{H}_{\text {str }}\right.$ and $\left.\mathrm{NH}_{\text {str }}\right) 3088\left(\mathrm{Ar} \mathrm{C}-\mathrm{H}_{\text {str }}\right), 1726\left(\mathrm{C}=\mathrm{O}_{\text {str }}\right) 1666-$ $1583\left(\mathrm{Ar} \mathrm{C}=\mathrm{C}_{\mathrm{str}}\right), 1064\left(\mathrm{C}-\mathrm{O}_{\mathrm{str}}\right), 885,835\left(\mathrm{C}-\mathrm{H}_{\mathrm{bend}}\right), 788\left(\mathrm{C}-\mathrm{Cl} \mathrm{str}_{\mathrm{str}}\right), 677\left(\mathrm{C}-\mathrm{Br}_{\mathrm{str}}\right)$.

Dye 5e. Yield 42\%; mp $270{ }^{\circ} \mathrm{C} ;{ }^{1} \mathrm{H}$ NMR (200 MHz, DMSO- $\left.\mathrm{d}_{6}\right) ; \delta_{\mathrm{h}}, \mathrm{ppm}: 2.41\left(\mathrm{~s}, 2 \mathrm{H}, \mathrm{NH}_{2}\right)$, 4.01 (s, $\left.{ }^{1} \mathrm{H}, \mathrm{Ar} \mathrm{OH}\right), 6.54-7.23(\mathrm{~m}, 2 \mathrm{H}, \mathrm{Ar} \mathrm{H}), 7.50-7.73(\mathrm{~m}, 2 \mathrm{H}, \mathrm{ArH}), 7.85-8.10$ (m, 4H, ArH); ${ }^{13} \mathrm{C}$ NMR $50 \mathrm{MHZ}$, DMSO-d ${ }_{6}$ ) $\delta \mathrm{c}, \mathrm{ppm}: 146.5,142.6,132.8,131.7,125.6,124.7$, (all C), 116.4, 41.8, 40.6, 40.3, 39.9, 39.7, 39.5, 38.7, $38.2\left(\right.$ all CH); IR $\left(\mathrm{v} \mathrm{cm}^{-1}\right): 3521,3401\left(\mathrm{Ar} \mathrm{O}-\mathrm{H}_{\text {str }}, \mathrm{N}-\right.$ $\left.\mathrm{H}_{\text {str }}\right), 3163-3059\left(\mathrm{Ar} \mathrm{C}-\mathrm{H}_{\text {str }}\right) 1695,1597\left(\mathrm{Ar} \mathrm{C}=\mathrm{C}_{\text {str }}\right), 1487(-\mathrm{N}=\mathrm{N}-)$ 1064, $1031\left(\mathrm{C}-\mathrm{O}_{\text {str }}\right), 846(\mathrm{C}-$ $\left.\mathrm{H}_{\text {bend }}\right), 786\left(\mathrm{C}-\mathrm{Cl}_{\text {str }}\right) 657\left(\mathrm{C}-\mathrm{Br}_{\text {str }}\right)$.

Dye 5f. Yield 54\%; mp $234{ }^{\circ} \mathrm{C},{ }^{1} \mathrm{H}$ NMR (200 MHz, DMSO-d $\left.{ }_{6}\right), \delta_{\mathrm{N}}, \mathrm{ppm}: 3.45\left(\mathrm{~s},{ }^{1} \mathrm{H}, \mathrm{Ar} \mathrm{OH}\right)$ $6.74(\mathrm{~m}, 2 \mathrm{H}, \mathrm{ArH}), 7.26-7.65(\mathrm{~m}, 2 \mathrm{H}, \mathrm{ArH}), 7.87-8.26(\mathrm{~m}, 2 \mathrm{H}, \mathrm{ArH}) ;{ }^{13} \mathrm{C}$ NMR $(50 \mathrm{MHz}$, DMSO-d ${ }_{6}$ ); $\delta \mathrm{c}$ ppm: $160.2,152.5,143.7,134.0,133.6,124.7,122.4,121.8,115.3$, (all C); 41.7, 40.9, 40.5, 40.1, 39.6, 38.8, 38.5 (all CH); IR $\left(\mathrm{v} \mathrm{cm}^{-1}\right): 3423\left(\mathrm{Ar} \mathrm{O}-\mathrm{H}_{\mathrm{str}}\right), 3188-3093\left(\mathrm{Ar} \mathrm{C}-\mathrm{H}_{\mathrm{str}}\right)$, 1678-1589 (Ar C= $\left.\mathrm{C}_{\text {str }}\right), 1479,1431(-\mathrm{N}=\mathrm{N}-), 1066\left(\mathrm{C}-\mathrm{O}_{\text {str }}\right), 885,833\left(\mathrm{C}-\mathrm{H}_{\mathrm{bend}}\right), 759\left(\mathrm{C}-\mathrm{Cl}_{\text {str }}\right)$, $677\left(\mathrm{C}-\mathrm{Br}_{\mathrm{str}}\right)$.

\section{Preparation of dye dispersions}

Each disperse solution of the dye sample was prepared by dissolving the dye $(1.0 \mathrm{~g})$ in dimethylformamide (DMF) $(5 \mathrm{~mL})$ and adding sodium lignin sulphonate $\left(0.5-1.0 \mathrm{gL}^{-1}\right)$ as the dispersing agent. The appropriate volume of the disperse solution was adjusted to $100 \mathrm{~mL}$.

\section{Dye application}

Dye dispersion $(10 \mathrm{~mL})$ was made up to $100 \mathrm{~mL}$ with the dispersing agent and placed in a dyebath. The liquor ratio used was 1:50. The $\mathrm{pH}$ of the dye liquor was adjusted to 5.5 by adding a few drops of acetic acid. Polyester fabric $(2 \mathrm{~g})$ was dipped inside the dye bath and dyeing was carried out according to high temperature and high pressure method [16]. The dyebath temperature was raised from 20 to $135{ }^{\circ} \mathrm{C}$ at a rate of $3{ }^{\circ} \mathrm{C} \mathrm{min}{ }^{-1}$ and this temperature was maintained for $1 \mathrm{~h}$ before cooling rapidly to $50{ }^{\circ} \mathrm{C}$. The dyed fabrics were at this stage rinsed with cold water and reduction cleared in aqueous solution containing sodium hydroxide $(2.0 \mathrm{~g}$ $\left.\mathrm{L}^{-1}\right)$ and sodium hydrosulphite $\left(1.0 \mathrm{gL}^{-1}\right)$. The dyed fabric was then soaped off (washing the dyed fabric with detergent to remove residual dye molecules) with $2 \%$ non-ionic detergent and ammonia (pH 8.5) at $50^{\circ} \mathrm{C}$ for $30 \mathrm{~min}$.

\section{Colour fastness to washing test}

The test for colour fastness to washing was determined using the ISO 105-CO6:2010 test method [17]. The cut dyed samples were sewed between two bleached pieces of wool and cotton fabric and placed into a bath containing an aqueous solution of $5 \mathrm{gL}^{-1}$ of a detergent (non-ionic) 
of liquor ratio 1:50. The bath was maintained thermostatically at $60{ }^{\circ} \mathrm{C}$ for $30 \mathrm{~min}$. After which, the samples were removed, rinsed and hand squeezed twice and dried. The washing fastness was then evaluated by comparing with the standard greyscale for change of color.

\section{Color fastness test to rubbing}

Color fastness to rubbing was measured according to ISO 105-X12: 2001 method [18]. The test is designed to ascertain the amount of color that could be transferred from the surface of the colored specimen to adjacent white fabric surface by rubbing. This test can be done on wet and dry fibres.

\section{Wet rubbing test}

The dyed polyester fabric specimen was thoroughly wetted with water and placed flat at the base of the tester. The white testing cloth was also mounted and lowered unto the test specimen. The finger of the tester carrying the weight of 2-6 $\mathrm{N}$ was placed in contact with the test specimen and was made to slide back and forth several times until ten complete turns was made at a rate of 1 turn s $\mathrm{s}^{-1}$. The staining on the white test sample was then evaluated using the standard greyscale.

\section{Dry rubbing test}

The dyed polyester fabric specimen was placed flat at the base of the tester. The procedure was then run as described for wet rubbing fastness test. The white test sample, $60 \mathrm{~mm}$ square, was removed and evaluated for staining using the grey scale (grade 1-5).

\section{Colour fastness to sublimation test}

The dyed polyester fabric specimen was subjected to sublimation treatment according to ISO 105-POI 1993 method [19]. The test was carried out at $177{ }^{\circ} \mathrm{C}$ for $30 \mathrm{~s}$. The polyester fabrics were then evaluated for colour change using the standard greyscale (grade 1-5) where 1 (poor), 5 (excellent).

\section{Colour fastness to light}

The dyed polyester samples were exposed to xenon arc lamp involving the use of continuous light for $35 \mathrm{~h}$. The change in color of the tested samples was recorded by comparing with the standard blue scale for color change. This test was carried out in accordance with ISO 105-BO2: 1988 method [20].

\section{RESULTS AND DISCUSSION}

The compounds yield range from 42-68 \% and the melting points of the dyestuffs vary from $150-270^{\circ} \mathrm{C}$. The dyes with one hydroxyl group exhibited high melting points $\left(170-270^{\circ} \mathrm{C}\right)$ while the lowest melting point was found for dye $5 \mathrm{~b}\left(150^{\circ} \mathrm{C}\right)$. The reason for this low melting point of dye $5 \mathrm{~b}$ could be attributed to the substituents on the benzene ring of the coupling components. All the dyes possess good solubility in dimethylformamide.

The FTIR spectra of the synthesised compounds showed a strong band between 3423 and $3520 \mathrm{~cm}^{-1}$ region, which corresponds to $\mathrm{O}-\mathrm{H}$ or $\mathrm{N}-\mathrm{H}$ stretching vibrations [21]. Absorption bands of $\mathrm{C}-\mathrm{H}$ in the IR spectra were observed between 3093 and $3186 \mathrm{~cm}^{-1}$. In the ${ }^{1} \mathrm{H}$ NMR spectra, the broad singlet peaks which appeared at $6.72-7.73 \mathrm{ppm}$ suggest the presence of $\mathrm{OH}$ in the synthesised dyes [22]. Absorption bands of $\mathrm{C}=\mathrm{C}$ stretching vibration were observed at 1583 $1675 \mathrm{~cm}^{-1}$ region, suggesting the presence of aromatic rings. 
All the $\mathrm{sp}^{2}$ carbons attached to the more electronegative atoms of the benzene rings such as $-\mathrm{Br},-\mathrm{Cl}$ and $-\mathrm{OH}$, showed absorptions at $\delta 141-167 \mathrm{ppm}$. This indicates that the $\mathrm{sp}^{2}$ carbons gave absorption down field due to the de-shielding effect of the carbons by the electronegative atoms. The other $\mathrm{sp}^{2}$ carbons of the aromatic compounds showed absorptions at $\delta 115-130 \mathrm{ppm}$. The absorption peaks observed at $\delta 38-67 \mathrm{ppm}$ were assigned to $\mathrm{sp}^{3}$ carbons.

\section{UV-Visible spectroscopic studies}

The results of the UV-vis spectroscopic analysis are presented in Table 1. The UV-vis spectra of the dyes exhibited typical electronic spectra with multiple absorptions in the UV region at about 274-400 $\mathrm{nm}$ also referred to as the B-band, and the others were observed in the visible region at $450-800 \mathrm{~nm}$ (Q-band). The Q-band is ascribed to $\mathrm{n}-\pi$ transition from the highest occupied molecular orbital (HOMO) to the lowest unoccupied molecular orbital (LUMO) of the $\pi$-conjugated chain of the dye molecules $[23,24]$. The absorption maximum of dye $\mathbf{5 a}$ occurred at $573 \mathrm{~nm}$ with no shoulder. That of dye $\mathbf{5 b}$ was observed at $646 \mathrm{~nm}$ with an intense and broad shoulder over $750 \mathrm{~nm}$. Dye 5c gave an absorption maximum at $596 \mathrm{~nm}$ and a shoulder extending into the near infrared region over $650 \mathrm{~nm}$. The absorption maximum of dye $\mathbf{5 d}$ is 604 $\mathrm{nm}$ and a red-shift shoulder at $784 \mathrm{~nm}$, extending and increasing beyond $800 \mathrm{~nm}$. Dye 5e gave absorption maximum at $464 \mathrm{~nm}$ with an intense shoulder, extending over $800 \mathrm{~nm}$. Dye $\mathbf{5 f}$ showed absorption maximum at $496 \mathrm{~nm}$ which extended beyond $600 \mathrm{~nm}$. Thus, the absorption maxima observed for the dyes appear to have been influenced by the aromatic substitution pattern of the rings. The multiple absorptions are attributed to the non-conjugative effects of the various chromophores present in the molecules [24, 25]. And the near-infrared absorption maxima observed in the dye compounds is a function of extensive electron delocalisation within the ring system along the chain, as well as the interaction of this delocalisation with the available heavy bromine atom.

Table 1. Absorption maxima of disazo disperse dyes $\mathbf{5 a}$ to $\mathbf{5} \mathbf{f}$ in dimethylformamide solution.

\begin{tabular}{|c|c|c|c|}
\hline Dye & B-Band $\left(\lambda_{\max }\right)$ & Q-Band $\left(\lambda_{\max }\right)$ & $\mathrm{R}_{\mathrm{f}}$ \\
\hline 5a & 274 & 573 & 0.60 \\
\hline 5b & 370 & 646,750 & 0.59 \\
\hline 5c & 267 & 596,650 & 0.62 \\
\hline 5d & 345 & 604,784 & 0.74 \\
\hline 5e & 352 & 464,800 & 0.82 \\
\hline 5f & 400 & 496,576 & 0.70 \\
\hline
\end{tabular}

Fastness to washing

All the dyes showed excellent fastness to washing of grade 5 (Table 2). Generally, the dyes are characteristically hydrophobic so high washing fastness values were expected according to standard greyscale. This may be attributed to an increase in the molecular size of the dyes and sufficient intra-fibre diffusion of molecules of the dye within the fabrics.

Table 2. Wash fastness properties of dyed polyester fabric ( $2 \%$ owf).

\begin{tabular}{|c|c|c|c|c|}
\hline \multirow{2}{*}{ Dye } & \multirow{2}{*}{ Change in color } & Cotton & Polyester & Nylon \\
\cline { 2 - 5 } & 5 & 5 & 5 & 5 \\
\hline $\mathbf{5 a}$ & 5 & 5 & 5 & $4-5$ \\
\hline $\mathbf{5 c}$ & 5 & 5 & 5 & $4-5$ \\
\hline $\mathbf{5 d}$ & 5 & 5 & 5 & 5 \\
\hline $\mathbf{5 e}$ & 5 & 5 & 5 & 5 \\
\hline $\mathbf{5 f}$ & 5 & 5 & 5 & $4-5$ \\
\hline
\end{tabular}




\section{Fastness to rubbing}

The test was actually carried out to determine the degree of color transfer from the surface of the dyed fabric to another adjacent undyed fabric surface by rubbing. The results in Table 3 showed that most of the dyes exhibited good rubbing fastness values of grade 4 and 3-4 which implies good, or very good results based on the standard greyscale. This performance may be attributed to sufficient dye diffusion into the fabrics.

Table 3. Sublimation, light and rubbing fastness properties of dyed polyester fabric.

\begin{tabular}{|c|c|c|c|c|}
\hline \multirow[b]{2}{*}{ Dye } & \multirow[b]{2}{*}{ Sublimation } & \multirow[b]{2}{*}{ Light } & \multicolumn{2}{|c|}{ Rubbing } \\
\hline & & & Dry & Wet \\
\hline $5 \mathbf{a}$ & 5 & $5-6$ & $3-4$ & $3-4$ \\
\hline $5 b$ & 5 & 5 & 4 & 4 \\
\hline $5 c$ & 5 & 6 & $3-4$ & $3-4$ \\
\hline $5 d$ & 5 & 5 & $3-4$ & $3-4$ \\
\hline $5 e$ & 5 & $5-6$ & 4 & $3-4$ \\
\hline $5 f$ & 5 & $6-7$ & 4 & 4 \\
\hline
\end{tabular}

Fastness to light

The prepared dyes showed satisfactory fastness to light, ranging from grade 5 to 6-7 according to the standard blue wool for change of color. The light fastness performance could be attributed to the presence of electron withdrawing groups in the vicinity of the azo group.

\section{Fastness to sublimation}

The fastness to sublimation treatment of the synthesized dyes was expressed in terms of color staining on undyed polyester pieces. The results (Table 3 ) show good to excellent ratings (grade 4 to 5). Generally, fastness to sublimation depends upon the substituents on the coupling component ring as well as those on the diazo component ring. Thus, substituents such as $\mathrm{OH}$, $\mathrm{NH}_{2}$ and other polar groups contributed to the high sublimation fastness of the dyes on polyester fabrics [26].

\section{CONCLUSION}

This study presented the synthesis and characterization of new sets of azo dyes and their fastness properties on polyester fabrics. The UV-Vis data of the synthesized azo compounds showed that they are potential near infrared absorbers and could be used as organic photoconductors and similar applications. The synthesized compounds showed good fastness properties on polyester fabrics and could be found useful in the production of textiles.

\section{REFERENCES}

1. Qian, G.; Wang, Z.Y. Near-infrared organic compounds and emerging applications. Chem. Asian J. 2010, 5, 1006-1029.

2. Otutu, J.O. Synthesis of halogenated disazo disperse dyes derived from 2,4-dichloroaniline and 3-aminophenol. Curr. Res. Chem. 2012, 4, 119-127.

3. Salem, M.A.I.; Marzouk, M.I.; Mashaly, H.M. Synthesis of pharmacological dyes and their application on synthetic fabrics. Color Technol. 2015, 131, 288-297.

4. Loutfy, R.O.; Hor, A.; Hsiao, C.; Baranyi, G.; Kazmaier, P. Organic photoconductive materials. Pure Appl. Chem. 1988, 60, 1049-1054.

5. Zhang, Z.; Achilefu, S. Design, synthesis and evaluation of near-infrared fluorescent $\mathrm{pH}$ indicators in a physiologically relevant range. Chem. Commun. 2005, 47, 5887-5889. 
6. Amiot, C.L.; Xu, S.; Liang, S.; Pan, L.; Zhao, J.X. Near-infrared fluorescent materials for sensing of biological targets. Sensors 2008, 8, 3082-3105.

7. Norena-Franco, L.E.; Kvansnit, F. Chemically sensitive films for the detection of hazardous substances employing cyanine and nitroso near infrared dyes. Analyst 1998, 123, 2185-2189.

8. Bae, C.; Kwag, G.; Kenney, M. Synthesis and characterization of near-infrared absorption tin octabutoxy naphthalocyanines. Polym. 2007, 26, 2810-2816.

9. Sakamoto, K.; Yoshino, S.; Takemoto, M.; Sugaya, K.; Kubo, H.; Komoriya, T.; Kamel, S.; Furukawa, S. Optical and electrochemical properties of non-peripheral thioaryl-substituted subphthalocyanine as precursors for dye-sensitizer to develop photovoltaic cells. Am. J. Anal. Chem. 2014, 5, 1037-1045.

10. Jokic, T.; Borisov, S.M.; Sat, R.; Nielsen, D.A.; Kuhi, M.; Klimant, I. Highly photostable near-infrared fluorescent $\mathrm{pH}$ indicators and sensors based on BF2-chelated tetraarylazadipyrromethene dyes. Anal. Chem. 2012, 84, 6723-6730.

11. Gordon, P.F.; Waring, D.R.; Hallas, G. The Chemistry and Application of Dyes, Plenum Press: London, England; 1990; pp. 381-405.

12. Wang, Z.Y.; Zhan, J.; Wu, X.; Birau, M.; Yu, G.; Yu, H.; Q1, Y.; Desjaandins, P.; Meng, X.; Gao, J.P.; Todd, E.; Song, N., Bai, Y.; Beaudin, A.M.R.; Leclair, G. Near-infrared absorbing organic materials. Pure Appl. Chem. 2004, 76, 1435-1443.

13. Otutu, J.O.; Efurhievwe, E.M.; Ameuru, S.U. Synthesis of disazo disperse dye compounds derived from 4-bromoaniline and 3-aminophenol as potential near infra-red absorbers. Chem. Mat. Res. 2014, 6, 40-46.

14. Park, J.M.; Jung, C.Y.; Yao, W.; Sung, C.Y.; Jaung, J.Y. Synthesis of yellow pyridonylazo colorants and their application in dye-pigment hybrid color filters for liquid crystal display. Color Technol. 2016, 133, 158-164.

15. Aysha, T.; El-Sedik, M.; Mashaly, H.M.; El-Apasery, M.A.; Machalicky, O.; Hrdina, R. Synthesis, characterisation, and applications of isoindigo/Pechmann dye heteroanalogue hybrid dyes on polyester fabric. Color Technol. 2015, 131, 333-341.

16. Qi, Z.; Ailin, Y.; Chunling, Z.; Shuyuan, B.; Haibo, W. Synthesis of methane dyes derived from indol-2-ones and their dyeability on polyester fibres. Color. Technol. 2013, 130, 27-31

17. ISO 105-CO6: 2010 Textiles: Tests for color fastness. Part CO6: Color fastness to domestic and commercial laundering, Basel: ISO; 2010.

18. ISO 105-X12: 2001 Textiles: Tests for color fastness. Part X12: Color fastness to rubbing, Basel: ISO; 2001.

19. ISO 105-PO1: 1993. Textiles: Tests for color fastness. Part PO1: Color fastness to sublimation, ISO; 1993.

20. ISO 105-BO2: 1988. Textiles: Tests for color fastness. Part BO2: Color fastness to artificial light: Xenon arc fading lamp test, Basel: $180 ; 1988$.

21. Morrison, R.T.; Boyd, R.N.; Bhattacharijee, S.K. Organic Chemistry, 7th ed., Pearson Education Limited: Essex, England; 2011, p 824.

22. Sadeek, S.A.; Zordok, W.A.; El-Attar, M.S.; Ibrahim, M.S. Spectroscopic, structural, thermal and antimicrobial studies of 4,6-bis(-chlorophenyl)-2-oxo-1,2-dihydropyridine-3carbonitrile with some transition metals. Bull. Chem. Soc. Ethiop. 2015, 29, 75-94.

23. Bruice, P.Y. Organic Chemistry, Prentice Hall: New Jersey, USA; 2001; p 514-523.

24. Vitnik, V.D.; Vitnik, Z.J.; Bozic, B.D.; Valentic, N.V.; Dilber, S.P.; Mijin, D.Z.; Uscumlic, G.S. Experimental and theoretical insight into the electronic properties of 4-aryl-5-arylazo-3-cyano-6-hydroxy-2-pyridone dyes. Color Technol. 2017, 133, 223-233.

25. Towns, A.D. Developments in azo disperse dyes derived from heterocyclic diazo components. Dyes Pig. 1999, 42, 3-28.

26. Shuttleworth, L.; Weaver M.A. The Chemistry and Application of Dyes, Plenum Press: London, England; 1994; p 16. 